\title{
Water Quality Study of Freshwater of Bekaa Valley to the Delta at Mediterranean Seawater in the region of Lebanon
}

\author{
Adnan Falah*, Husein Yemendzhiev, Valentin Nenov \\ Department of Water Treatment, Faculty of Technical Sciences, Burgas "Prof. Asen Zlatarov" University, Burgas, Republic of Bulgaria \\ Received: 06/06/2020 \\ Accepted: 26/09/2020 \\ Published: 20/12/2020
}

\begin{abstract}
The water quality of fresh water, springs and wells in Bekaa valley, mountain district, a region of Republic of Lebanon in connection/delta of Mediterranean sea (basin) is surveyed along the Lebanese north, central and south coast at Tripoli, Jounieh and Saida deltas respectively in which, Sannine Aquifer at Bekaa valley, the major groundwater source for the coastal area is in-direct contact with the sea. The thin freshwater lens (delta) is being heavily exploited in this area, where a large number of wells exist in the area passing coas tal areas of Lebanon. Many of those wells are saline and are not suitable for direct domestic use or even for irrigation. This study deals with water quality study, general assessment of level of pollution and potential influence on seawater through analysis of Physico-Chemical parameters and selected Inorganic substances of water sample collected from south, central and north Lebanese coastal water among with major water natural resources at Bekaa valley.
\end{abstract}

Keywords: Water Quality, Bekaa Valley, Mediterranean Sea, Lebanon

\section{Introduction}

Water demand has been continuously increasing and at higher rates in most parts of the world and Lebanon is no exception. Controlling agricultural water demand is extremely important, especially in Lebanon, where about $70 \%$ of water demand is for the agricultural sector. Lebanon is a multi-morphological country including mountains, valleys and plains. The Bekaa Valley is a fertile land passage, separating the Mount Lebanon and AntiLebanon ranges, drained to the North by the Aassi River (or Orontes) and to the South by the Litani River. Bekaa extends for $4,167 \mathrm{~km}^{2}$ and represents $40 \%$ of the national territory. Morphological and geological features are the main factors that make Lebanon a country with rich and renewable water resources compared to other nearby countries [1-7]. Furthermore, about 65 $\%$ of Lebanon is covered by karstic rocks and natural water resources characterized by springs, caves and sinkholes. These aquifers are highly beneficial, nonetheless extremely exposed to water contamination due to anthropogenic activities such as quarries, waste depositing and sewage. The main water sources in the Bekaa Valley come from surface water, springs and underground aquifers. The controlling factor of the underground water is the combination of geological structures and composition [8]. The complex structure of the karstic rocks of the AntiLebanon unit is one of the most important holding deposits of water in the region; numerous springs form the important surface drainage system of the Bekaa Valley. These formations have characteristics for good quality water and are mainly exploited as domestic water resources via wells or springs [9, 10]. The hydrogeological assets of the Bekaa Valley are strongly characterized by the surface water system and its relationship with the underground aquifers. There are various drainage systems, most of which are dried for most of the year and highly influenced by snow melting. Two main rivers flow to south of Lebanon called Litani river and to the north called Aassi (Oronte) with a division path near the Baalbeck area, the historical city in Bekaa province in Lebanon [11-13]. This study is carried out though analysis of spring/wells of Bekaa valley and Litani river at the delta to Mediterranean basin of Lebanon (Figure 1 and 2), the landform created by deposition of sediment that is carried by the concerned river as the flow leaves its path end and enters slowermoving to the seawater of Lebanese coast.

\section{Materials and Methods}

Mediterranean Seawater (basin) at the delta and freshwater/well water samples from different locations in Lebanon were collected directly from the source with different depths equal to 2, 3 and 5 meters and samples stored properly in a plastic bottle. Water collected in triplicate meaning three bottles for each sample. All samples are collected-in and analysed within eight hours of collection, Physico-chemical parameters such as

\footnotetext{
*Corresponding author: Adnan Falah, Burgas "Prof. Asen Zlatarov" University, 8010, Y. Yakimov str.1, Burgas, Republic of Bulgaria,
} E-mail: adnan@falahpwp.com 
$\mathrm{pH}$, temperature $\left({ }^{\circ} \mathrm{C}\right.$ ), electrical conductivity (microsiemens per centimetre, $\mu \mathrm{S} / \mathrm{cm})$, dissolved oxygen, total dissolved solids (TDS), alkalinity, salinity and hardness measured in ppm were analysed using portable device called "Multi Parameters Portable Water Quality Monitor "PWQM" Wagtech) that is capable of performing all tests listed above.

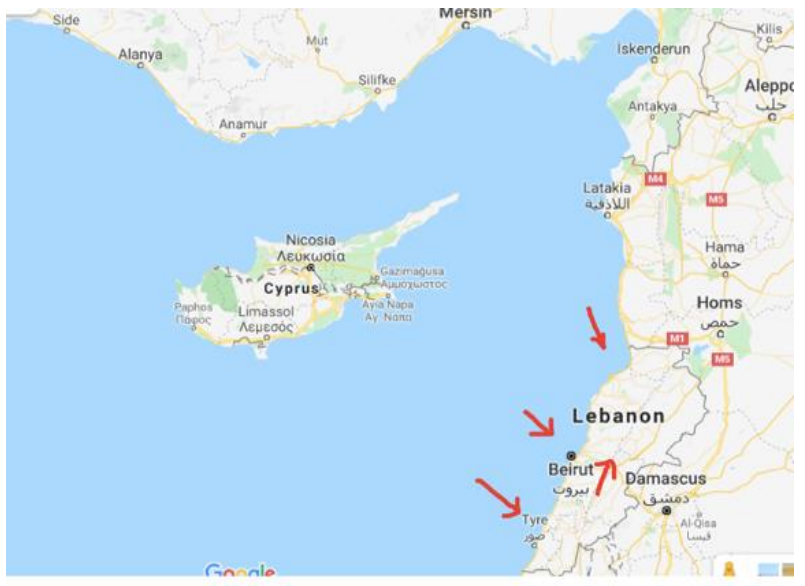

Figure 1: General map of Lebanon at Mediterranean Basin and study areas of Bekaa Valley and coastal water

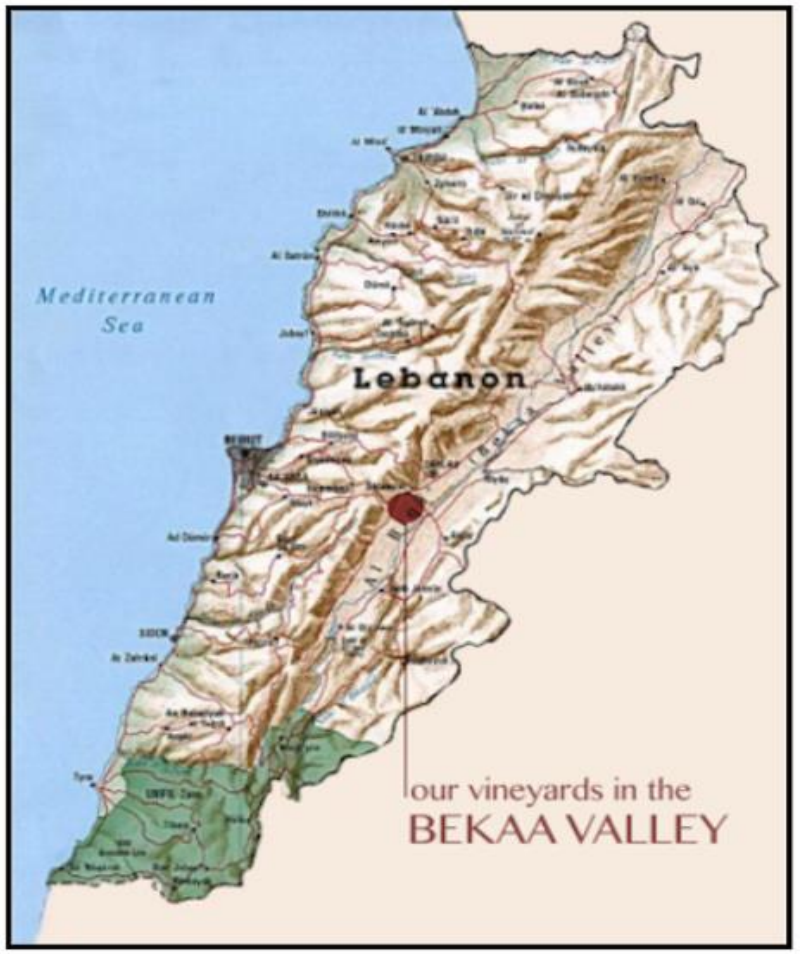

Figure 2: General view of Bekaa Valley and coastal line of Lebanon

The Calibration of this multi-tester was done at the beginning of every sampling day using standard calibration solutions for $\mathrm{pH}$ and conductivity to ensure reliability of the test results and quality. The tester was well dipped by distilled water after each testing process. The measuring cup was dipped few times with each water sample to be tested. Prior to each sampling process, adequate volume of water was removed first by pumping to ensure that standing water either in the well or in pipes was discarded. UV/Vis spectrophotometer with appropriate reagents and test Kits from Merck Spectroquant were used to determine the concentration of Inorganic substances like calcium, magnesium, sodium, potassium, iron, fluoride, nitrate, sulphate and phosphate in water at specific wavelength $(\lambda \mathrm{nm})$. Mohr method was used for chloride concentration. Agents and chemicals used for water analysis experiment were of analytical grade [14-18]. Sample collection; Sea water samples were collected from three different regions in Lebanon along the coastal area of Jounieh, Tripoli and Saida (Figure 1), few hundred meters away from the shore and from different depths (2, 3 and 5 $\mathrm{m})$ in fact, average concentrations were calculated and presented. Different samples of fresh water were collected from along the course of the stream starting from their sources (wells, springs) from Bekaa Valley at Mountain Lebanon area (Figure 1 and 2), were taken from each area and analysed to match the existing information and obtain indication of potential pollution sources that might be from primarily sewage, agriculture as well as saltwater interruption with the delta [19].

\section{Results and Discussions}

The seawater results of samples analysis at the delta for Jounieh, Tripoli and Saida coastal line (Figure 1) are shown in Tables 1. Upon investigating the tabulated data, it is found that Mediterranean basin/seawater at the delta has an average of $\mathrm{pH}$ equal to 8.90 where electrical conductivity was $63,550 \mu \mathrm{S} / \mathrm{cm}$. Moreover, average total dissolved solids reported at $40,110 \mathrm{ppm}$ were salinity found to be $42,228 \mathrm{ppm}$ so that hardness as $\mathrm{CaCO}_{3}$ detected at 3,550 ppm where calcium average is $715.00 \mathrm{ppm}$. Other elements were also analyzed in order to have complete assessment of water quality especially at the delta in which springs and fresh water direct in-contact with the sea. The average concentration of magnesium recorded at $1,840 \mathrm{ppm}$ as well as concentration of sodium, potassium, chloride and fluoride found to be $5,640,144,24,900$ and $15 \mathrm{ppm}$ respectively. No indication of iron concentration seen. Besides, pollution level is also studied, and data shows level of sulphate at $2,530 \mathrm{ppm}$ where concentration at $8.50 \mathrm{ppm}$ is for nitrate and finally phosphate test recorded at average concentration equal to $26.90 \mathrm{ppm}$. It seems the averages for all three coastal line water regions in table 1, are similar to each other; this might be due to large area of thin freshwater lens at the delta (Figure 3) [20-24]. The $\mathrm{pH}$ and chloride levels (average) are found to be fairly close to the standard values reported in the literature which are 8.90 and $24,900 \mathrm{ppm}$ respectively. The reported range for calcium levels in seawater vary from 350 to $1,500 \mathrm{ppm}$ and based on date obtained in table 1 found to be within the average $(715.00 \mathrm{ppm})$. The total dissolved solids value is quite greater than the reported value $35,000 \mathrm{ppm}$ [13]. The range of salinity in the open ocean is about 31,000 to $38,000 \mathrm{ppm}$ while the salinity value obtained for Mediterranean basin is $40,110 \mathrm{ppm}$. The obtained values of potassium and magnesium are within the normal range [14]. The proportions of inorganic species are within the expected allocations for seawater (Figure 4). However, the three coastal regions show quite high phosphate values. This is due to the fact that the samples have been taken from shallow sea water where the potential of having wastewater discharges into the sea is high. High rates of organic decay can produce localized saturation of 
phosphate in seawater. Water carrying pesticides and fertilizers from very near to sea agricultural lands can lead to elevated values of nitrate concentration as can be seen from the results $[25,26]$. The low dissolved oxygen values obtained in the three regions along the Lebanese coast ranging from 5.87 to $6.22 \mathrm{ppm}$ are an indication of organic pollution of sea water. This might be due to excessive dumping of garbage, waste and sewage into the sea especially in the regions close to the shore [17].

Table 1: Analysis of Physico-Chemical properties and concentrations of selected inorganic substances of water samples from three different regions in Lebanon along the coastal area of Jounieh, Tripoli and Saida

\begin{tabular}{|c|c|c|c|}
\hline \multirow{2}{*}{ Test Name } & \multicolumn{3}{|c|}{ Concentration } \\
\hline & Jounieh & Tripoli & Saida \\
\hline Temperature $\left({ }^{\circ} \mathrm{C}\right)$ & 27.80 & 28.77 & 26.77 \\
\hline pH & 8.10 & 7.87 & 7.98 \\
\hline Electrical Conductivity $(\mu \mathrm{S} / \mathrm{cm})$ & $62,220.02$ & $64,880.01$ & $61,000.00$ \\
\hline Dissolved Oxygen (mg/) & 6.11 & 5.87 & 6.22 \\
\hline Resistance $(\Omega . c m)$ & 15.11 & 14.22 & 15.34 \\
\hline ORP (mv) & 231.98 & 255.11 & 245.99 \\
\hline TDS (mg/l) & $40,540.22$ & $40,110.02$ & $39,400.00$ \\
\hline Salinity (ppm) & $41,440.00$ & $42,200.00$ & $37,100.00$ \\
\hline Phosphate (mg/l) & 27.88 & 23.00 & 35.09 \\
\hline Total Hardness (mg/l) & $2,133.07$ & $3,854.00$ & $2,390.00$ \\
\hline Calcium (mg/l) & 683.00 & 877.09 & 707.98 \\
\hline Fluoride (mg/l) & 14.33 & 10.87 & 9.90 \\
\hline Iron (mg/) & 0.02 & 0.00 & 0.00 \\
\hline Magnesium (mg/l) & 954.44 & $1,819.27$ & $1,988.00$ \\
\hline Alkalinity (mg/l) & 977.33 & $1,650.33$ & $1,340.10$ \\
\hline Sulfate (mg/) & $3,132.09$ & $2,720.99$ & $2,103.98$ \\
\hline Chloride (mg/) & $25,776.98$ & $25,133.09$ & $25,100.00$ \\
\hline Nitrates $(\mathrm{mg} / \mathrm{l})$ & 8.89 & 14.40 & 10.50 \\
\hline Sodium (mg/l) & $6,200.00$ & $4,280.98$ & $5,760.00$ \\
\hline Potassium (mg/l) & 106.09 & 90.11 & 344.09 \\
\hline
\end{tabular}

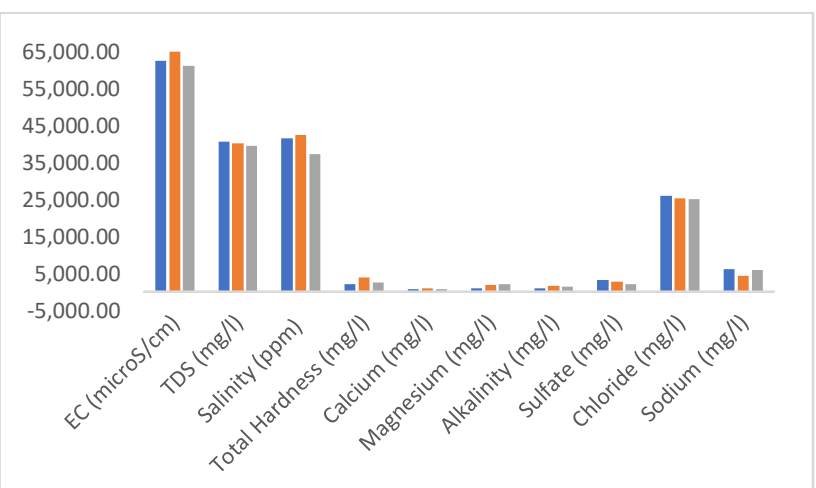

Figure 3: Comparison analysis and concentrations of selected physical parameters and inorganic substances of water samples from Jounieh (Left), Tripoli (Middle) and Saida (Right)

On the other hand, water quality in the Bekaa Inland were investigated, samples were taken from both wells and springs in the Bekaa region. Groundwater constitutes the major source of fresh water in Lebanon. Bekaa Valley relies by $90 \%$ on groundwater resources for agriculture and domestic use. The results shown in Table 2 is assessed. and it is found that chemical constituents of the Bekaa spring water values are below the upper permissible limits imposed by USA-EPA (Environmental protection agency) and WHO (World health organization) for drinking water; knowing that the upper permissible limit of sulfate in drinking water is $400 \mathrm{mg} / \mathrm{l}$. It should be noted that nitrates in high concentration in drinking water is harmful to human health. Water hardness is equivalent to the concentration of $\mathrm{Ca}^{2+}$ and $\mathrm{Mg}^{2+}$.

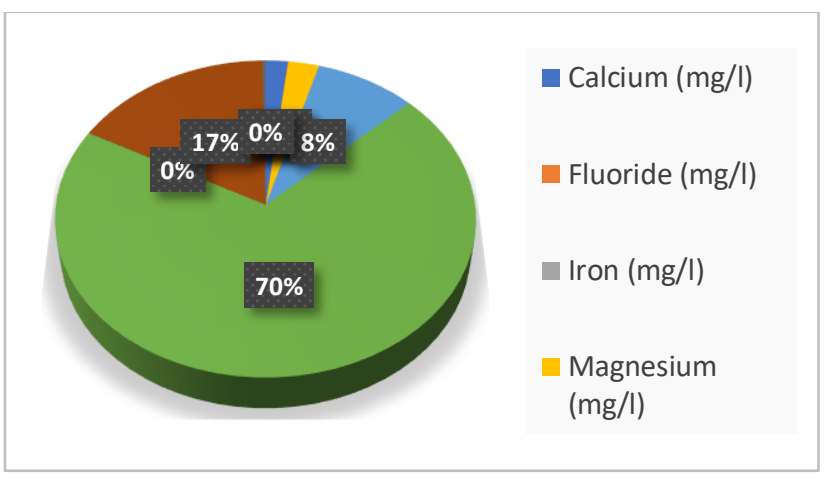

Figure 4: Relative proportions (Average) of dissolved salts in seawater

It reflects the nature of the geology in the area of the stream. Samples with hardness values between 200 and 300 ppm CaCO3 are considered hard water and have a bitter taste. It could also be shown from the results that the well/spring water average has a high electrical conductivity value; this quality of water with high average of EC could be harmful to plants or other organism [1825 ]. Figure 5 illustrate the relative distribution proportions (average) of dissolved salts in Bekaa Valley well/spring water where, Sodium and Chloride have the higher portion of $74 \%$ and $15 \%$ respectively. Other extended analysis data are tabulated in Table 2. Spring water in Bekaa valley is significantly used for drinking, in farming, irrigation and industrial activities. The Bekaa itself, is Lebanon's largest province and has the largest area of arable land to date. It has a moderate dry and warm climate in summers and wet to snowy winters (Mediterranean climate). The Bekaa is located about $30 \mathrm{~km}$ east of Lebanon's capital Beirut. The Bekaa valley is situated between Mount Lebanon to the west and the Anti-Lebanon mountains to the east. It is $120 \mathrm{Km}$ long and $16 \mathrm{Km}$ wide on average. Diversely, threats to its water supplies would severely affect the economy of the province. The Bekaa valley is a huge agricultural land with a fertile soil and low population compared to other provinces [19-21]. Most towns and villages in the Bekaa Valley have no significant sewer systems thus, notable portion of wastewater discharged untreated into a nearby valley. Litani river, the important water resource in southern Lebanon which is rises in the fertile Bekaa Valley (west of Baalbek historical city of Bekaa province) and empties into the Mediterranean Sea at north delta of Lebanon. Many towns and areas among Litani River had a sewer system installed in the early 1990s, but its waste flows, untreated, into the adjacent Litani River. During the summertime, when the river's flow slows to its minimum, the problem becomes more serious due to excess amount of waste and backlogs in the sewer system that affect the river flows mood. Since many unscrupulous farmers inn towns and cities are known to draw water from the river to irrigate their summer crops, which they market locally and in Beirut capital. The impacts on people's health as a result of the farmers' use of contaminated irrigation water remain undocumented. However, by referring to the obtained results and compare them with the reported values in literatures, the potential influence of Bekaa valley's water (fresh, well, springs) to the seawater quality became sharper to spot. 
Table 2: Analysis of Physico-Chemical properties and average concentrations of selected inorganic substances of water samples from Bekaa Valley Well/Spring water that in contact with Sea at the delta in Lebanon (Mediterranean Basin)

\begin{tabular}{|c|c|}
\hline Test Name & Concentration \\
\hline Temperature $\left({ }^{\circ} \mathrm{C}\right)$ & 24.10 \\
\hline pH & 7.55 \\
\hline Electrical Conductivity $(\mu \mathrm{S} / \mathrm{cm})$ & $2,148.80$ \\
\hline Dissolved Oxygen (mg/l) & 333.09 \\
\hline TDS (mg/l) & 656.01 \\
\hline Salinity (ppt) & 115.22 \\
\hline Phosphate (mg/l) & 112.12 \\
\hline Total Hardness (mg/l) & 220.01 \\
\hline Calcium (mg/l) & 5.65 \\
\hline Fluoride (mg/l) & 3.11 \\
\hline Iron (mg/l) & 0.20 \\
\hline Magnesium (mg/l) & 33.11 \\
\hline Sulfate (mg/l) & 100.21 \\
\hline Chloride (mg/l) & 200.12 \\
\hline Nitrates (mg/l) & 1.50 \\
\hline Sodium (mg/l) & 995.22 \\
\hline Potassium (mg/l) & 10.12 \\
\hline
\end{tabular}

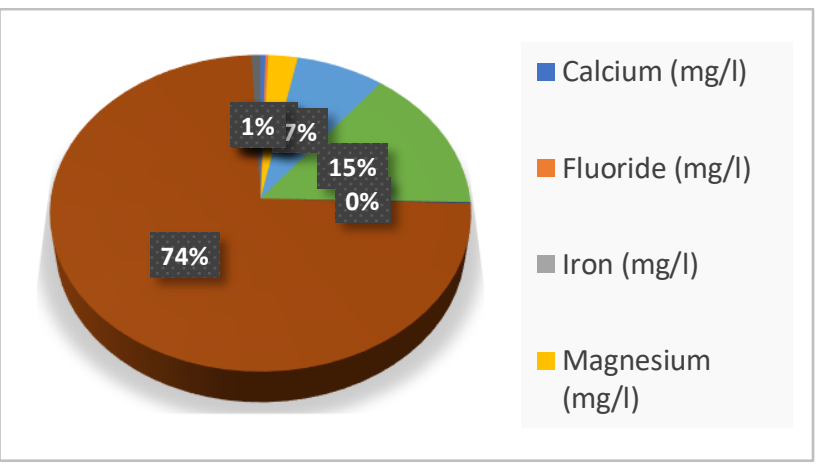

Figure 5: Relative distribution proportions (Average) of dissolved salts in Bekaa Valley well/spring water

The Lebanese coastal zone is the most perceptive zone in the country, it is expands over $210 \mathrm{~km}$ in length in which industrial, commercial, entertainments, beeches, resorts and financial activities along with major Lebanese cities are generally concentrated; mixing salinity zone or the fresh-salt water that is in-direct contact with seawater from rivers and wells especially from Bekaa valley, has exceeded the limit which requires more attention to sustain desirable quality of water. Though, coastal aquifers, a natural gradient still exists towards the coast and groundwater discharges from areas of higher groundwater levels into the sea. This naturally occurring movement of fresh water in fact, prevents saltwater from entering freshwater coastal aquifers. The flow of saltwater inland, or horizontal seawater encroachment, is limited to coastal areas. As we go further inland, the freshwater head is higher thus, it is able to equalize the pressure from the saltwater, preventing saltwater interference so that a saline wedge below the fresh water is formed and the density is high enough to prevent substantial mixing and thus a natural hydrostatic equilibrium is developed in fact, any change in the recharge values due to climatic changes or extensive human activities or untreated flows, affects the naturally occurring equilibrium negatively and that is the case now; greater recharge shifts the interface towards the sea whereas any deficit in this recharge causes seawater violation into coastal fresh water aquifers. Moreover, the quality of seawater at the delta is in deterioration state due to lack of treatment from the sources such as Litani river and other fresh water entering the seawater. On the other hand, drilling a huge number of wells to high depths and exploited at high rates is speeding the rate of seawater interference and making new paths for seawater flow in fact, seawater continue to encroach inland which coincides with areas of high population densities. The potential impact from excess wells usage in the concerned areas meaning that residents are producing the extensive over abstraction of the coastal aquifers mainly Sannine aquifer since it is in-direct contact with the sea. Thus, at these focused zones, groundwater is no more fresh and the situation is thought to become much worse if people continue to exploit the groundwater at the same way [26-31].

\section{Conclusions}

Based on data compared in Table 1 and 2 with and standards in literatures, it seems that groundwater quality of a different parts of the Bekaa Valley is getting poor to very poor-quality characteristics. Water management and further monitoring are highly required to treat contaminated water and reduce sources of pollution. Groundwater over the studied areas are not protected and more strategies needed to inhibit loss. Groundwater managing laws and regulations exist, however they are not strictly enforced. However, Water quality for drinking and irrigation purposes need to be managed based on standards regulations. Continuous monitoring of groundwater as well as sea water at the delta is required especially for the areas of agricultural, for constructing better management plans. This study might add and providing useful data and awareness for future observations and better managements [32].

\section{Ethical issue}

Authors are aware of, and comply with, best practice in publication ethics specifically with regard to authorship (avoidance of guest authorship), dual submission, manipulation of figures, competing interests and compliance with policies on research ethics. Authors adhere to publication requirements that submitted work is original and has not been published elsewhere in any language.

\section{Competing interests}

The authors declare that there is no conflict of interest that would prejudice the impartiality of this scientific work.

\section{Authors' contribution}

All authors of this study have a complete contribution for data collection, data analyses and manuscript writing.

\section{References}

1 Pimentel, D. et al. 1997. Water resources: agriculture, the environment and society. Bioscience 47(2): 97-106.

2 ESCWA (Economic and Social Commission for Western Asia). 1998. Survey of economic and social developments in the ESCWA 
region 1997-1998. United Nations, New York, NY, USA. E/ESCWA/ED/1998/5. 194 pp.

3 FAO (Food and Agriculture Organization of the United Nations). 1997. Irrigation in the Near East in figures. FAO, Rome, Italy. 137 pp.

4 Gregersen, H.M.; Draper, S.; Elz, D. 1989. People and trees: the role of social forestry in sustainable development. World Bank, Washington, DC, USA.

5 Tuijil, W. 1993. Improving water use in agriculture: experience in the Middle East and North Africa. World Bank, Washington, DC, USA. 158 pp.

6 ESCWA Countries, 27-30 Oct, Manama, Bahrain. Economic and Social Commission for Western Asia, New York, NY, USA. E/ESCWA/ENR/1997/WG.3/CP.3. pp. 36-42

7 Hamdan, F. Waste trade in the Mediterranean: toxic attacks against Lebanon, Green Peace Mediterranean Office, Malta,1995.

8 Hassan H. Hammud, "Determination of Soil Pollution as a Result of Solid Waste", Unesco Chair for Environmental Protection, , 20 September 1998, Homos - Syria.

9 Hassan H. Hammud, "Determination of Heavy Metals Toxic to Plants in Lebanese water and Soil", Unesco Chair for Environmental Protection, 19 September 1999, Homos - Syria.

10 Hassan H. Hammud, "Quality and Pollution Studies of Water in Lebanon", Ultra Science - Dimension of Pollution, 1, 19, (2001).

11 Eaton, A., Clesceri, L., Greenberg, A., and Franson, M., Standard Methods for the examination of water and waste Quality, APHA (1995).

12 Web page: www.sea water quality.com

13 Web page: www.aquacraft.net

14 Ahmad Kabbani, Hassan H. Hammud, Nisrine Afifi, and Adonis Mounzer, "Dissolved Oxygen and Water Hardness in Iklemm ElKharroub and South Lebanon", International Conference on Research Trends in Science and technology, RTST, 109-113, (2002).

15 Michael Pidwirny, Fundamentals of Physical Geography (2nd edition), University of British Columbia, Okanagan, Canada, 2006. Web page: www.physicalgeography.net

16 Hassan H. Hammud, "Water Quality Studies of Damour and Litani", Le Premier Colloque Franco - Libanais sur L'eau et La Sante, 15-17 October 1998, Beirut - Lebanon.

17 Ahmed Kabbani, Hassan H. Hammud, Hanaa Itani, and Halaa Itani "Spring Water of Lebanese Bekaa Valley", Ultra Science Dimension of Pollution, 1, 48, (2001).

18 Integrated Water Resources Management in CAMP, ARD, 2003.

19 Rohmann, S. O., Hayes, J. J., Newhall, R. C., Monaco, M. E., \& Grigg, R. W. (2005). The area of potential shallow-water tropical and subtropical coral ecosystems in the United States. Coral Reefs, 370383.

20 OWOW - US EPA. (2005, October). Coral Reefs. Retrieved January 16, 2012, from Office of Wetlands, Oceans, and Watersheds - USA.

21 Shabib, M., Al Abed, I., \& Hellyer, P. (2001). United Arab Emirates: a new perspective. London: Trident Press.

22 Henderson, J. C. (2006). Tourism in Dubai: overcoming barriers to destination development. International Journal of Tourism Research , 87-99.

23 Rezai, H., Wilson, S., Claereboudt, M., \& Riegl, B. (2004). Coral Reef Status in the Ropme Sea Area: Arabian/Persian Gulf, Gulf Of Oman and Arabian Sea in Status of Coral reefs of the World. (Townsville: Australian Institute of Marine Science) , 155-170.

24 Hughes, T. P., Graham, N. A., Jackson, J. B., Mumby, P. J., \& Steneck, R. S. (2010). Rising to the challenge of sustaining coral reef resilience. Trends in Ecology and Evolution , 619-680.

25 Ahmed Kabbani, Hassan H. Hammud, Hanaa Itani, and Halaa Itani "Spring Water of Lebanese Bekaa Valley", Ultra Science Dimension of Pollution, 1, 48, (2001).

26 Ahmad Kabbani, Hassan H. Hammud, Nisrine Afifi, and Adonis Mounzer, "Dissolved Oxygen and Water Hardness in Iklemm ElKharroub and South Lebanoný", International Conference on Research Trends in Science and technology, RTST, 109-113, (2002).
27 Hassan Hammud, "Water Quality Studies of Damour and Litani", Le Premier Colloque Franco Libanais sur L'eauet La Sante, Beirut, Lebanon, (1998).

28 Falah, A., El Khatib, R., Yahfoufi, N. (2012). Water Quality Survey of Arabian Peninsula in Regions of Dubai in the United Arab Emirates. Canadian Journal on Chemical Engineering \& Technology, 1-6.

29 Sayigh, Y.A. 1978. The economies of the Arab World. Croom Helm, London, UK. 29. Pimentel, D. 1997. Water resources: agriculture, the environment and society. Bioscience 47(2): 97-106.

30 Srour, S.; Sleiman, B. 1998. Water management plan for the Litani River and Karoun reservoir. "Workshop on Pollution in the Litan River and Lake Karoun, and Environmental Problems in the Western Bekaa and Rashaya", 9-10 May, Lebanon.

31 Jaber, B.A. 1997. Development and Use of Non-conventional Water and Appropriate Technology to Manage Groundwater in the ESCWA Countries, 27-30 Oct, Manama, Bahrain. Economic and Social Commission for Western Asia, New York, NY, USA E/ESCWA/ENR/1997/WG.3/CP.3. pp. 36-42.

32 Nimee, M. 1998. The effects of agriculture on pollution in the Litani watershed and Karoun Lake, and the use of irrigation water. "Workshop on Pollution in the Litani River and Lake Karoun, and Environmental Problems in the Western Bekaa and Rashaya, 9-10 May, Lebanon. 